\title{
On the composition of orcine and its derivatives
}

\section{Laurent \& Gerhardt}

To cite this article: MM. Laurent \& Gerhardt (1848) On the composition of orcine and its derivatives, Philosophical Magazine Series 3, 33:222, 322-323, DOI: 10.1080/14786444808646107

To link to this article: http://dx.doi.org/10.1080/14786444808646107

曲 Published online: 30 Apr 2009.

Submit your article to this journal

Џll Article views: 2

Q View related articles 두 


\section{ON THE COMPOSITION OF ORCINE AND ITS DERIVATIVES. BY MM. LAURENT AND GERHARDT.}

Chemists generally admit the formulæ proposed some years since by M. Liebig, for dry and crystallized orcine. According to this chemist, they are-

$$
\begin{array}{ll}
\text { Dry orcine ......... } & \mathrm{C}^{16} \mathrm{H}^{16} \mathrm{O}^{4} \\
\text { Crystallized orcine. . } & \mathrm{C}^{16} \mathrm{H}^{16} \mathrm{O}^{4}+3 A q .
\end{array}
$$

These formulæ seem at first to agree perfectly with the metamorphoses by which orcine originates, and especially with the production of orcine by lecanorine. But if the formulæ of M. Liebig be compared with the analyses of $M$. Dumas, and with the more recent ones of MM. Will and Schunck, whose results are almost identical with those of M. Dumas, it will be seen that these formulæ suppose an error of nearly 3 per cent. in the carbon found by experiment in dry orcine.

Struck with this circumstance, one of the authors proposed two years since to reject the formula of M. Liebig, and to replace them by the following :-

$$
\begin{aligned}
& \text { Dry orcine.......... } \mathrm{C}^{7} \mathrm{H}^{8} \mathrm{O}^{8} \\
& \text { Crystallized orcine } \ldots . \quad \mathrm{C}^{7} \mathrm{H}^{8} \mathrm{O}^{2}+\text { Aq. }
\end{aligned}
$$

These not only agree very well with the analyses of orcine, but also with those of lecanorine and other crystallizable derivatives.

MM. Laurent and Gerhardt state that they have lately obtained with orcine a new derivative, the composition of which confirms the latter formule. This compound is bromorcine, a substance which crystallizes in fine silky needles, and is easily produced by the action of bromine on orcine. The formula of bromorcine is $\mathrm{C}^{7} \mathrm{H}^{3} \mathrm{~B}^{3} \mathrm{O}^{2}$, and it consequently represents orcine, in which three equivalents of hydrogen are replaced by three equivalents of bromine. It is remarkable that potash dissolves it immediately, and becomes of a very deep violet-brown colour. It was found to contain $23 \cdot 1$ per cent. of carbon, the authors' formula requiring $23 \cdot 2$. If the proportions of M. Liebig were supposed to be correct, the authors state that they must have committed an error of nearly 2 per cent. in the same way as $\mathrm{M}$. Dumas in his experiments on normal orcine.

The authors' formulæ place orcine in relation with the salicylic series ; they form an isomeric with the saligenine of M. Piria. The following are the relations which exist, according to MM. Laurent and Gerhardt, between orcine and its crystallizable derivatives.

Lecanorine: by ebullition with barytes water, it gives carbonate and orcine :-

$$
\begin{aligned}
& \mathrm{C}^{16} \mathrm{H}^{14} \mathrm{O}^{7}+\mathrm{H}^{2} \mathrm{O}=2\left[\mathrm{CO}^{2}+\mathrm{C}^{7} \mathrm{H}^{8} \mathrm{O}^{2}\right. \\
& \text { lecanorine }
\end{aligned} \text { orine. }
$$

Pseuderythrine : by boiling with alcohol and an alkali, lecanorine gives carbonate, orcine and pseuderythrine:

$$
\begin{aligned}
& \mathrm{C}^{16} \mathrm{H}^{14} \mathrm{O}^{7}+\mathrm{C}^{2} \mathrm{H}^{6} \mathrm{O}=\mathrm{CO}^{9}+\mathrm{C}_{7}^{7} \mathrm{H}^{8} \mathrm{O}^{2}+\mathrm{C}^{10} \mathrm{H}^{12} \mathrm{O}^{4} \text {. } \\
& \text { lecanorine alcohol orcine pseuderythrine. }
\end{aligned}
$$


The alkalies when boiling transform pseuderythrine into carbonate, alcohol and orcine :

$$
\underset{\text { pseuderythrine }}{\mathrm{C}^{10} \mathrm{H}^{12} \mathrm{O}^{4}+\mathrm{H}^{2} \mathrm{O}=\mathrm{CO}^{2}+\mathrm{C}^{2} \mathrm{H}^{6} \mathrm{O}+\mathrm{C}^{7} \mathrm{H}^{8} \mathrm{O}^{2} .} \text { alcohol orcine. }
$$

The formulæ by which the authors represent lecanorine and pseuderythrine agree perfectly with the analyses of MM. Schunck, Liebig, Kane, Rochleder and Heldt.

As to orceine, which is a red uncrystallizable colouring matter, the following relations agree very well with the analysis of $M$. Dumas :

$$
\begin{aligned}
& \mathrm{C}_{7} \mathrm{H}^{8} \mathrm{O}^{2}+\mathrm{O}^{9}+\mathrm{NH}^{3}=2 \mathrm{H}^{2} \mathrm{O}+\mathrm{C}^{7} \mathrm{H}^{2} \mathrm{NO}^{9} \text { orceine. } \\
& \text { orcine }
\end{aligned}
$$

Comptes Rendus, Août 1848.

\section{ON PSEUdOQUINA-A NEW ALKALOID. BY M. MENGARDUQUE.}

M. Pelouze had in his laboratory an extract of cinchona, the source of which was uncertain; he gave it to the author for examination as an exercise. 'This substance was of a deep brown colour, friable, very bitter, slightly soluble in water, soluble in acids, which it saturated like the alkaloids, and formed true saline solutions, from which water precipitated it as a pitchy mass. This matter, treated by the processes for the extraction of quina and cinchonia, did not yield the least trace of either of these alkaloids; nor was the cinchovatine of M. Manzine met with in it; but the author was so fortunate as to discover an alkaloid which he believes to be new, and which he so described as to leave no doubt in the mind of $M$. Pelouze, who witnessed his experiments.

This alkaloid differs from the substances by which it is accompanied in the extract, in saturating acid more perfectly, insomuch that it expels ammonia from its compounds, like lime or barytes; it scarcely dissolves even in boiling sther, and of these properties advantage was taken in order to effect its separation.

The extract was boiled with an equal weight of hydrochlorate of ammonia till ammonia ceased to be evolved. On cooling, a very ajundant brown matter was deposited of a syrupy consistence, upon which floated a limpid liquid of a light amber colour. This liquor, poured off and filtered, was precipitated by ammonia.

The product thus obtained was yellowish and flocculent, suscep. tible of softening, and agglutinating by heat. It was dried and treated with cold æther, which dissolved the greater part of it, and left a pulverulent white matter, which was the new alkaloid in a state of purity.

This product, thus purified, possessed the following characters: subjected to heat on platina foil it fuses, and then burns with a blue flame without leaving any residue. It is insoluble in water and inaipid, soluble in alcohol, and much more so when hot than cold; its 